критерия равной площади Кинда. Моделирование выполнено с помощью демонстрационной версии программы Micro-Cap 11. Модель позволяет предсказать вольт-секундную характеристику различных воздушных промежутков. Модель рассматривается как вспомогательное средство для студентов, изучающих курс техники высоких напряжений

ключевые слова: схемотехническое моделирование, техника высоких напряжений, электрический пробой, вольт-секундная характеристика, критерий равной площади.

Trotsenko Yevgeniy, PhD, Associate Professor, Department of High Voltage Engineering and Electrophysics, National Technical University of Ukraine «Igor Sikorsky Kyiv Polytechnic Insti-
tute»,Ukraine, e-mail:y.trotsenko@kpi.ua, ORCID: http://orcid.org/ 0000-0001-9379-0061

Brzhezitsky Volodymyr, Doctor of Technical Sciences, Professor, Department of High Voltage Engineering and Electrophysics, National Technical University of Ukraine «Igor Sikorsky Kyiv Polytechnic Institute», Ukraine, e-mail: v.brzhezitsky@kpi.ua, ORCID: http:// orcid.org/0000-0002-9768-7544

Masluchenko Igor, PhD, Associate Professor, Department of High Voltage Engineering and Electrophysics, National Technical University of Ukraine «Igor Sikorsky Kyiv Polytechnic Institute», Ukraine, e-mail:i.masluchenko@kpi.ua,ORCID: http://orcid.org/0000-00016073-9649

\title{
Khabiuk A., Danalakiy 0. RESEARCH OF OPERATION OF ANISOTROPIC OPTICAL THERMOELEMENT WITH LATERAL TEMPERATURE REGULATION
}

Розв'язано неоднорідне рівняння теплопровідності з урахуванням закону Бугера для поздовжнього перерізу круглого ииліндра з термоелектрично-анізотропного матеріалу. Отримано вирази для поперечної термоЕРС та характеристик радіаційного анізотропного оптикотермоелементу (АОТЕ), що дає змогу контролювати величину потоку енергї в області оптичної прозорості матеріалу, з якого він виготовлений. Описана конструкція приладу на основі радіаційного АОТЕ з боковим термостатуванням.

Ключові слова: радіаційний анізотропний оптикотермоелемент (АОТЕ), поперечна термо EPC, AOTE з боковим термостатуванням.

\section{Introduction}

The wide use of thermoelectric devices as sources of electric energy, coolers and measuring equipment is due to their reliability, high service life, ability to work under extreme conditions and ecological purity. Thermoelectric devices are used in space and defense technology, metrology, electronics, medicine, etc.

The basis of most thermoelectric devices is a semiconductor thermocouple element, which, along with positive qualities, has drawbacks that prevent further progress in the development of thermoelectricity. The principal shortcomings of the thermocouple element include the ineffective participation of its volume in thermoelectric energy conversion, switching problems, and limitations on the Q-factor of the used materials. Therefore, the further development of thermoelectricity by searching for semiconductor materials with a higher quality factor has already almost exhausted itself.

Progress in thermoelectricity is possible with the introduction of new thermoelements (TE), which are dominated by the possibilities of thermocouple elements. Among the new promising TEs there are vortex TEs with unique properties, which are based on the use of the effect of vortex thermoelectric currents (VTC). It is possible to indicate, in particular, spiral vortex thermoelements, in which the problem of commutation and obtaining the necessary stresses is solved [1,2].

However, the elemental base of thermoelectricity needs replenishment due to the creation of new types of thermoelements based on known thermoelectric phenomena and phenomena that have not been sufficiently studied. To known phenomena, the mechanisms of their origin have been studied, but on the basis of which TE is created, for example, the volume effects of Peltier and Bridgman can be attributed. Studies of the feasibility of creating anisotropic optical thermoelements (AOTE) on these effects on the basis of existing and hypothetical materials, as well as studying the depth of their cooling, are of current interest. Such studies could lead to the creation of AOTE for cooling or stabilizing the temperature of various kinds of microsensors and microelectronic devices, and are distinguished by a simpler design than the known ones. To the insufficiently studied phenomena from the point of view of practical application it is possible to attribute umkehr effect, VTC effect, the effect of the anisotropy of thermal conductivity on the transverse thermoelectric power.

An in-depth study of the influence of the anisotropy of thermal conductivity on the temperature field and the transverse thermoelectric power of electrically insulated AOTE and its energy would lead to a refinement of the 
physical processes in it and expansion of the field of its application.

\section{The object of research and its technological audit}

The object of research is direct mutual conversion of thermal and electric energy using anisotropic thermoelectric media.

The subject of research is physical processes in AOTE and the possibilities of their practical use.

The present time is characterized by an increase in information needs and, consequently, the development of media means. Hence the promise of using thermoelectricity to solve information problems arises. With thermoelectric means, it is possible to effectively measure temperatures, heat flux densities, radiation powers, etc. Thus, the creation and use of new types of thermoelements should be directed primarily to the creation of information technology devices.

To register the radiant flux, AOTE is used. On their basis, through-type radiant energy receivers have been created, containing optically transparent heat sinks, to which AOTE are attached by means of an adhesive dielectric layer [3, 4]. Such heat sink, while ensuring a reliable removal of the heat generated in TE, leads nevertheless to a significant distortion of the amplitude-phase characteristics of the transmitted radiant flux, thus limiting the energy and time characteristics of the receivers. Therefore, the problem of creating such receiver design, which would be free of these shortcomings, is promising. One of the variants of the constructive solution of this problem is given in this paper.

\section{The aim and objectives of research}

The aim of research is the discovery of new AOTEs, the study of physical processes, the processes in which they occur, the determination of their application areas, and the improvement in the characteristics of standard AOTE by constructive changes.

To achieve this aim, it is necessary to solve the following tasks:

1. To study the effect of heat inflow inside the AOTE through the lateral faces on the temperature distribution in their middle part, depending on the ratio of geometric dimensions.

2. To find the possibility of creating new AOTE, which can be used to cool or stabilize the operating temperature of various kinds of microdevices.

\section{Research of existing solutions of the problem}

The first results of experimental studies of the umkehr effect in AOTE are given in [6, 7]. It is shown that for certain orientations of the magnetic field induction and the temperature gradient relative to the crystallographic axes of the Bi single crystal, the inversion induction of the magnetic field leads to a change in the magnitude and sign of the longitudinal thermoelectric power. The physical nature of this phenomenon was first elucidated in $[8,9]$, in which the dependence of the longitudinal thermoelectric power on the direction of induction of the transverse magnetic field was studied in the direction of the temperature gradient.

AOTE is considered from the standpoint of a onedimensional temperature model, which was used in [10-12]. A one-dimensional temperature model was also used in [13]. The essence of this model is that the AOTE sample, which is in a transverse magnetic field, or has a transverse thermoelectric power, exhibits either the Ettingshausen effect or the transverse Peltier effect, so long that the effects on the end faces can be neglected. That is, the flow of heat inside the AOTE through the ends does not affect the processes occurring in its middle part. In this case it is assumed that in the middle part of the sample the temperature is one-dimensional, and the electric field along the current direction is constant. The creation of new AOTEs was considered in [14]. The disadvantage of these studies is that the calculation of the performance characteristics did not take into account the dependence of the thermoelectric power on the inversion of magnetic field induction. This dependence was to some extent taken into account by the author when studying the work of AOTE in the mode of electric energy generation and partly in the cooling mode in [15]. However, a number of important issues remained unresolved.

\section{Methods of research}

Let's consider AOTE, which is made of optically transparent in a given frequency range and material in the form of a circular cylinder 1 of radius a and height $b$ with a temperature-controlled lateral surface at the temperature $T_{0}$ (Fig. 1).

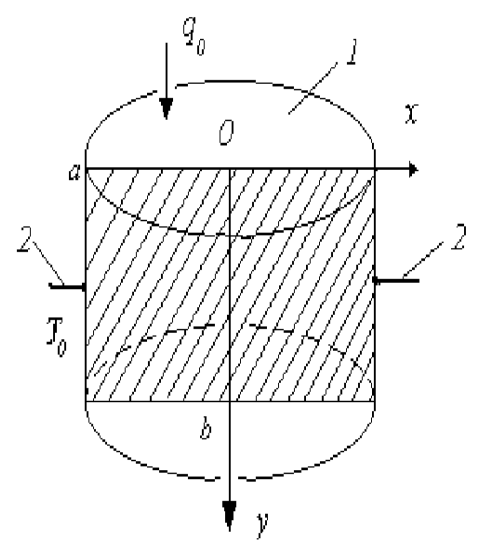

Fig. 1. Scheme of an anisotropic optical thermoelement, which is used to calculate the temperature distribution

The crystallographic axes with the maximum and minimum thermoelectric power are located in the $(x, y)$ plane. In Fig. 1 hatching shows the direction of the crystallographic axis, electrical probes for measuring the thermoelectric power -2 . The orientation of the crystallographic axes is selected when the maximum transverse thermoelectric power is obtained [16].

Neglecting the reflection of the incident monochromatic radiant flux $q_{0}$ at the AOTE boundaries $(y=0$ and $y=b$ ), let's represent the generalized heat equation taking into account Bouguer's law in the form:

$$
\frac{d^{2} T}{d x^{2}}+\frac{d^{2} T}{d y^{2}}+\frac{q_{0} \gamma}{\chi} e^{-\gamma y}=0,
$$


where $\chi, \gamma-$ coefficients of heat conductivity and absorption, respectively, which are considered as a constant.

Equations (1) are valid for any section $(x, y)$, since $\chi$ is isotropic. In this setting, the isothermal lines for each of the planes $y=$ const are concentric circles. The third term in (1) is the internal heat source. This equation must be considered together with the boundary conditions:

$$
\begin{aligned}
& T(-a, y)=T(a, y)=T_{0}, \\
& \frac{d T(x, 0)}{d y}=\frac{d T(x, b)}{d y}=0 .
\end{aligned}
$$

The conditions (3) follow from the requirements for the continuity of the heat flux at the boundaries $(y=0$ and $y=b)$.

Let's write the solution of equation (1) in the form of a Fourier expansion in cosines:

$$
T(x, y)=T_{0}+f_{0}(x)+\sum_{n=1}^{\infty} f_{n}(x) \cos \delta_{n} y,
$$

where $\delta_{n}=n \pi / b, \quad f_{0}-$ zero term of the expansion.

Substituting (2) into (1), obtain:

$$
f_{0}^{\prime \prime}(x)+f_{n}^{\prime \prime}(x)-\delta_{n}^{2} f_{n}(x)+C_{0}+C_{n}=0,
$$

where $C_{0}, C_{n}$ - coefficients of the Fourier series expansions in the cosines of the function:

$$
\left(q_{0} \gamma / \chi\right) \exp (-\gamma y)
$$

which have the form:

$$
\begin{aligned}
& C_{0}=\frac{2 q_{0}}{\gamma b}\left(1-e^{-\gamma b}\right), \\
& f_{0}^{\prime \prime}(x)-\delta_{n}^{2} f_{n}(x)+C_{n}=0 .
\end{aligned}
$$

From these equations obtain:

$$
\begin{aligned}
& f_{n}(x)=\frac{C_{n}}{\delta_{n}^{2}}+A_{n} e^{\delta_{n} x}+B_{n} e^{-\delta_{n} x}, \\
& f_{0}(x)=-\frac{1}{2} C_{0} x^{2}+G x+F .
\end{aligned}
$$

where $A_{n}, B_{n}, G, F$ - constants of integration.

Using the boundary conditions (4) and expressions (2), (6), (7), write:

$$
\begin{aligned}
& \frac{C_{n}}{\delta_{n}^{2}}+A_{n} e^{\delta_{n} a}+B_{n} e^{-\delta_{n} a}=0, \\
& \frac{C_{n}}{\delta_{n}^{2}}+A_{n} e^{-\delta_{n} a}+B_{n} e^{\delta_{n} a}=0, \\
& -\frac{1}{2} C_{0} a^{2}-G a+F=0,
\end{aligned}
$$

$$
-\frac{1}{2} C_{0} a^{2}+G a+F=0
$$

From the first two equations find:

$$
A_{n}=B_{n}=-\frac{C_{n}}{\delta_{n}^{2}} \frac{1}{2 c h \delta_{n} c},
$$

and two other will give:

$$
G=0, F=C_{0} a^{2} / 2 .
$$

So the temperature distribution will look like:

$$
T(x, y)=T_{0}+\frac{1}{2} C_{0}\left(a^{2}-x^{2}\right)+\sum_{n=1}^{\infty} \frac{C_{n}}{\delta_{n}^{2}} \frac{\operatorname{ch} \delta_{n} a-\operatorname{ch} \delta_{n} x}{\operatorname{ch} \delta_{n} a} \cos \delta_{n} y .
$$

The potential difference between the points $(a, b / 2)$ and $(-a, b / 2)$ (probes 2 in Fig. 1) has the value:

$$
\Delta \varphi=2 \alpha_{12} \sum_{n=1}^{\infty} \frac{C_{n}}{\delta_{n}^{2}}\left(\delta_{n} a-\frac{s h \delta_{n} a}{\operatorname{ch} \delta_{n} a}\right) \sin \frac{\delta_{n} b}{2} .
$$

Substituting $C_{n}$ and $\delta_{n}$ instead of their value for the potential difference $\Delta \varphi$, get:

$$
\begin{aligned}
& \Delta \varphi=\frac{4 \alpha_{12} q_{0} \gamma^{2} b^{2}}{\pi^{2} \chi} \sum_{n=1}^{\infty} \frac{1-(-1)^{n} e^{-\gamma b}}{n^{2}\left(n^{2} \pi^{2}+b^{2} \gamma^{2}\right)} \times \\
& \times \frac{n \pi a c h \frac{n \pi a}{b}-b \operatorname{sh} \frac{n \pi a}{b}}{c h \frac{n \pi a}{b}} \sin \frac{n \pi}{2} .
\end{aligned}
$$

The potential difference $\Delta \varphi$ is a thermoelectric power, which is due to the presence of the incident radiant heat flux $q_{0}$, anisotropy of the thermoelectric power factor $\alpha_{12}$, thermal conductivity $\chi$ and absorption $\gamma$. The potential difference depends on the geometric dimensions of the AOTE $a$ and $b$.

In the case of applying the considered AOTE as the sensor of the flow-through receiver under conditions $a>b, \gamma b<<1$ for the potential difference $\Delta \varphi$ with great accuracy, write:

$$
\Delta \varphi=\frac{8}{\pi} \frac{\alpha_{12}}{\chi} q_{0} a(\gamma b)^{2} .
$$

The volt-watt sensitivity is represented by the expression:

$$
S=8 \cdot 10^{-2} \alpha_{12} \gamma^{2} b^{2}(\chi a)^{-1} .
$$

The equivalent noise power $P$ of a given receiver has the form:

$$
P=2.5 \cdot 10^{-2} \chi a\left(\alpha_{12} \gamma\right)^{-1}\left(k_{0} T \sigma b\right),
$$

The time constant:

$$
\tau=4 a^{2}\left(\pi a_{0}\right)^{-1}
$$

Maximum density of controlled energy $q_{\max }$ : 


$$
q_{\max }=2 \Delta T \chi\left(\gamma a^{2}\right)^{-1} .
$$

In the above expressions: $k_{0}$ - the Stefan-Boltzmann constant; $a_{0}, \sigma, \Delta T-$ thermal diffusivity, electrical conductivity and permissible temperature of AOTE material overheating, respectively.

\section{Research results}

Table 1 shows the parameters of real optically transparent crystals that have anisotropy of the thermoelectric power coefficient at $300 \mathrm{~K}$ [17].

Table 1

Materials for manufacturing of anisotropic thermoelements

\begin{tabular}{|c|c|c|c|c|c|}
\hline $\begin{array}{c}\text { Mate- } \\
\text { rial }\end{array}$ & $\begin{array}{l}\text { Optical } \\
\text { trans- } \\
\text { mission } \\
\text { area } \lambda \text {, } \\
\mu m\end{array}$ & $\begin{array}{c}\text { The optical } \\
\text { absorption } \\
\text { coefficient } \gamma \text {, } \\
\mathrm{Cm}^{-1}\end{array}$ & $\begin{array}{l}\text { Coefficient of } \\
\text { transverse } \\
\text { thermoelectric } \\
\text { power, } \Delta \alpha, \\
\mu V \mathrm{~K}^{-1}\end{array}$ & $\begin{array}{c}\begin{array}{c}\text { Coefficient } \\
\text { of thermal }\end{array} \\
\text { conductivity, } \\
\begin{array}{cc}\mathrm{W} \mathrm{cm}^{-1} \\
\mathrm{~K}^{-1}\end{array}\end{array}$ & $\begin{array}{c}\text { Coefficient } \\
\text { of electrical } \\
\text { conduc- } \\
\text { tivity, } \sigma \\
\Omega^{-1} \mathrm{~cm}^{-1}\end{array}$ \\
\hline CdSb & $2.6-40.0$ & $0.1-0.3$ & $100-300$ & $1.510^{-2}$ & 0.3 \\
\hline ZnSb & $2.4-27.0$ & $0.4-0.8$ & 100-200 & $1.110^{-2}$ & 1.5 \\
\hline $\mathrm{CdAs}_{2}$ & $1.25-16.0$ & $0.5-1.0$ & $250-450$ & $310^{-2}$ & 0.03 \\
\hline $\mathrm{ZnAs}_{2}$ & $1.36-21.0$ & $0.8-1.2$ & $180-360$ & $6 \quad 10^{-2}$ & 0.01 \\
\hline CdS & $0.5-18.0$ & $0.2-0.8$ & 120-220 & $210^{-1}$ & 0.6 \\
\hline
\end{tabular}

The use of materials in Table 1 allows to create the construction of various anisotropic thermoelectric elements:

- time-stable through-type receivers with a volt-watt sensitivity of $\mathrm{S}=10^{-6}-10^{-3} \mathrm{~V} / \mathrm{W}^{-1}$

- working area $0.1-5.0 \mathrm{~cm}^{2}$ with the maximum value of the energy flux density $q_{\max }=10^{-3}-10^{1} \mathrm{~W} / \mathrm{cm}^{2}$ in a wide spectral range, with the possibility of using them as a filter.

Based on AOTE, the design of the laser radiation receiver is developed (Fig. 2). With the help of this receiver, it is possible to determine the energy distribution of the radiant flux over the cross section of the beam in a wide spectral and energy range, which is protected by the patent of Ukraine [18].

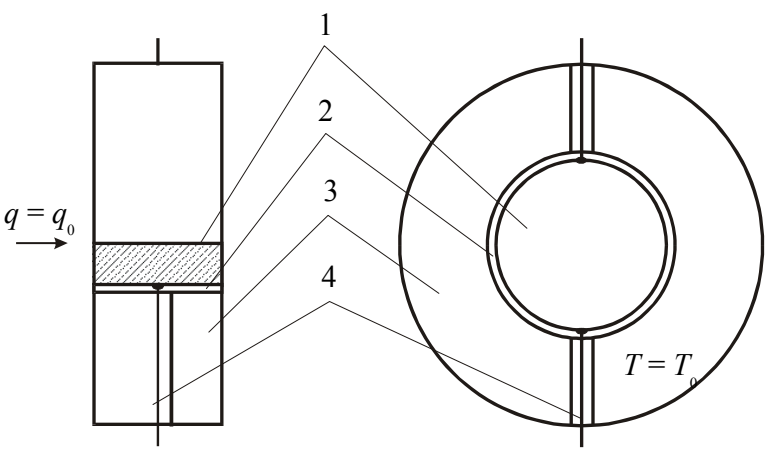

Fig. 2. Design of a thermal radiation receiver based on anisotropic optical thermoelement: 1 - anisotropic optical thermoelement; 2 - heat conducting electrical insulating ring; 3 - thermostat; 4 - electrical connections

An anisotropic optical thermoelement is widely used in measuring technology. New anisotropic optical thermoelements are effectively used to register and measure energy flows. They are indispensable in the study, for example, of powerful laser radiation. In the field of nitrogen temperatures and below, the use of galvanothermomagnetic cooling devices for cooling and stabilizing the temperature of various microsensors and microelectronic devices is prospective.

\section{SWOT analysis of research results}

Strengths. The strength of the research is the study of the nature of physical processes in thermoelectric media, which are the basis for the invention of the original elements that are important from a practical point of view and the study of phenomena in them.

Weaknesses. The weak side of research is the neglect of the dependence of the thermoelectric power on the inversion of magnetic field induction (umkehr effect), which is significant limits these possibilities.

Opportunities. In the future, it is necessary to investigate the effect of magnetic field induction inversion (umkehr effect) on longitudinal AOTE characteristics and to analyze the possibility of creating on the basis of the obtained AOTE results, whose operation principle is based on the umkehr effect. It is also necessary to propose and investigate physical models of longitudinal AOTE based on the Thomson effect, the volume Peltier effect and the Bridgman effect in terms of maximum temperature reduction.

The introduction of research results in production will allow to determine the economic efficiency from the current costs associated with their use in production. The profit from the introduction of the developed receiver of thermal radiation at the enterprise will be $100 \mathrm{c}$. u. [18].

Threats. When calculating the temperature distribution and efficiency, it is assumed that the temperature distribution is two-dimensional, the electric current density, which is produced by AOTE, is constant, the kinetic parameters of the AOTE material are also constant. Efficiency depends on the values of heat flow and external electrical resistance. Numerically, for modern thermoelectric homogeneous anisotropic materials it can reach $\sim 0.8 \%$. Such AOTE can be used as a thermal radiation sensor.

Estimates of all financial costs from the introduction of a thermal radiation receiver based on an anisotropic optical thermoelement in the enterprise will amount to $0.007 \%$ of the cost of this device [18].

\section{Conclusions}

1. It is shown that anisotropic thermoelectric elements with a working area of $0.1-5.0 \mathrm{~cm}^{2}$ with a maximum value of the energy flux density of $10^{-3}-10^{1}$ in a wide spectral range give optimal cooling of the equipment.

2. Design of a radiant flux receiver based on an anisotropic optical thermoelement is developed and tested, and the amplitude-phase characteristics of the flow do not change during passage. The receiver can be used as a filter or a semitransparent mirror of an optical resonator. Such effect is due to the fact that at a thickness of $1 \mathrm{~cm}$ AOTE is selected with parameters $\alpha=10^{-4} \mathrm{~V} / \mathrm{K}$, $\chi=10^{-2} \mathrm{~W} /(\mathrm{cm} \mathrm{K}), \rho=10^{-3} \Omega$, current $I=10 \mathrm{~A}$ and temperature of the thermostat $300 \mathrm{~K} \mathrm{~cm}$ gives the minimum temperature of $239 \mathrm{~K}$.

\section{References}

1. Korn, G. A. Mathematical Handbook for Scientists and Engineers: Definitions, Theorems, and Formulas for Reference and 
Review (Dover Civil and Mechanical Engineering) [Text] G. A. Korn, T. M. Korn. - Dover Publications, 2000. - 1152 p. 2. Lansberg, G. S. Optika [Text] / G. S. Lansberg. - Moscow: Nauka, 1996. - 927 p.

3. Ascheulov, A. A. Radiatsionnyi anizotropnyi optikotermoelement s bokovym termostatirovaniem [Text] / A. A. Ascheulov, V. G. Ohrem // TKEA. - 2014. - № 1. - P. 45-47.

4. Ascheulov, A. A. EDS anizotropnogo termoelementa v rezhime opticheskogo propuskaniia [Text] / A. A. Ascheulov, V. M. Kondratenko, Yu. B. Piliavskii, I. M. Rarenko // FTP. - 2014. Vol. 18, № 7. - P. 1330-1331.

5. Samoilovich, A. G. Sovremennoe sostoianie termoelektricheskih i termomagnitnyh iavlenii v poluprovodnikah [Text]. Part 1. Termodinamicheskaia teoriia / A. G. Samoilovich, L. L. Korenblit // UFN. - 1984. - Vol. 49, № 3. P. $243-272$

6. Wolfe, R. Experimental Verification of the Kelvin Relation of Thermoelectricity in a Magnetic Field [Text] / R. Wolfe, G. E. Smith // Physical Review. - 1963. - Vol. 129, № 3. P. 1086-1087. doi:10.1103/physrev.129.1086

7. Wolfe, R. Negative thermoelectric figure of merit in a magnetic field [Text] / R. Wolfe, G. E. Smith, S. E. Haszko // Applied Physics Letters. - 1963. - Vol. 2, № 8. - P. 157-159 doi:10.1063/1.1753823

8. Smith, G. E. Analysis of the transport phenomena in bismuth [Text] / G. E. Smith, R. Wolfe // J. Phys. Soc. Japan Suppl. 2016. - Vol. 21. - P. 651-656.

9. Goldsmith, H. J. Thermoelectric refrigiration [Text] / H. J. Goldsmith. - London, 2014. - $246 \mathrm{p}$

10. Harman, T. C. Thermoelectric and thermomagnetic effects and applications [Text] / T. C. Harman, J. M. Honig. - New-York: Mc Graw-Hill book Company, 2010. - 377 p.

11. Kooi, C. F. Thermoelectric-Thermomagnetic Energy Converter Staging [Text] / C. F. Kooi, R. B. Horst, K. F. Cuff // Journal of Applied Physics. - 1968. - Vol. 39, № 9. - P. 4257-4263. doi:10.1063/1.1656957

12. Delves, R. T. The prospects for Ettingshausen and Peltier cooling at low temperatures [Text] / R. T. Delves // British Journa of Applied Physics. - 1962. - Vol. 13, № 9. - P. 440-445 doi:10.1088/0508-3443/13/9/302

13. Harman, T. C. Erratum: Operating characteristics of transverse (nernst) anisotropic galvano-thermomagnetic generators [Text] / T. C. Harman, J. M. Honig // Applied Physics Letters. - 1963. - Vol. 2, № 2. - P. 44-48. doi:10.1063 1.1753765
14. Ohrem, V. G. Issledovaniia vliianiia inversii magnitnogo polia na termoEDS [Text]: PhD thesis: 01.04 .10 / V. G. Ohrem. Chernovtsy, 2002. -98 p.

15. Ascheulov, A. A. Anizotropnyi termoelement vnutrennego opticheskogo otrazheniia [Text] / A. A. Ascheulov, I. V. Gutsul, I. M. Rarenko // UFZh. - 2003. - Vol. 38, № 6. - P. 923-927.

16. Ascheulov, A. A. Anizotropnyi radiatsionnyi termoelement dlia izmerenii prohodnoi moshchnosti [Text] / A. A. Ascheulov // Optikomehanicheskaia promyshlennost'. - 2015. - № 12. - P. 48-49.

17. Anisotropic thermoelectric thermal radiation detector [Electronic resource]: Patent of Ukraine № 63394 A, MKB 7 H101L32/02 / Ascheulov A. A., Ohrem V. G. - Publ. 15.01.2004. - Available at: \www/URL: http://uapatents.com/2-63394-anizotropnijjtermoelektrichnijj-prijjmach-viprominyuvannya.html

18. Patent of Ukraine / Danalakiy O.; Institute of Thermoelectricity. - Appl. № 200304264; Filed 11.042003; Publ. 15.04.2014, Bull. № 1. -6 p.

\section{ИССЛЕДОВАНИЕ РАБОТЫ АНИЗОТРОЛНОГО ОПТИКОТЕРМОЭЛЕМЕНТА С БОКОВЫМ TEPMOСТАТИРОВАНИЕМ}

Решено неоднородное уравнение теплопроводности с учетом закона Бугера для продольного сечения круглого цилиндра с термоэлектрически-анизотропного материала. Получены выражения для поперечной термоЭДС и характеристик радиационного анизотропного оптикотермоэлемента (АОТЭ), что позволяет контролировать величину потока энергии в области оптической прозрачности материала, из которого он изготовлен. Описана конструкция прибора на основе радиационного АОТЭ с боковым термостатированием.

Ключевые слова: радиационный анизотропный оптикотермоэлемент (АОТЭ), распределение температуры, АОТЭ с боковым термостатированием.

Khabiuk Andrii, Postgraduate Student, Department of Pscyhology, Pedagogics and Social Management, National University «Lvi Polytechnic», Ukraine, e-mail: kym-ua@ukr.net, ORCID: http:// orcid.org/0000-0001-7151-9043

Danalakiy Oleh, PhD, Associate Professor, Department of Information Systems, Chernivtsi Faculty of the National Technical University «Kharkiv Polytechnic Institute»,Ukraine, e-mail: ogdanalaki@gmail.com, ORCID: http://orcid.org/0000-0002-6602-9506

\section{Bezvesilna 0., Chepyuk L., Tkachuk A. Nechai 5. Khylchenko T.}

\section{ANALYSIS OF MODERN GRAVIMETERS OF THE AVIATION GRAVIMETRIC SYSTEM}

Обгрунтовано доцільність використання авіащійних гравіметричних систем для проведення гравіметричних вимірювань та отримання інформації про гравітаційне поле Землі. Проведено аналіз існуючих съогодні гравіметрів авіачійних гравіметричних систем, визначено їх переваги та недоліки. Розглянуто сучасні перспективні розробки у галузі створення авіаційних гравіметрів нового типу із вищою точністю та швидкодією у порівнянні з відомими на свогодні аналогами.

Кпочові слова: чутливий елемент, гравіметр, прискорення сили тяжіння, гравітаційне поле Землі.

\section{Introduction}

Research of parameters of the gravitational field of the Earth (gravitational acceleration (GA) g and its anomalies $\Delta \mathrm{g})$ is necessary in:
- seismology, (earthquake prediction);

- aviation and space technology (correction of systems of inertial navigation of rockets, aircraft, orbits of spacecraft);

- for research of geodynamic phenomena; 